\title{
Release of All Legal Demands (Ontslag Van Recht Vervolging) In Judgment's Consideration
}

\author{
Andi Kusuma Mapareppa ${ }^{*}$ and Jawade Hafidz ${ }^{* *}$ \\ *) Student of Master of Law, Faculty of Law, Universitas Islam Sultan Agung (UNISSULA) \\ Semarang, E-mail: shumaa26@gmail.com \\ ${ }^{* *}$ Faculty of Law, Universitas Islam Sultan Agung (UNISSULA)
}

\begin{abstract}
.
This study aims to identify and explain the basic position of judges' considerations in issuing a decision free from all lawsuits for the accused and to analyze the development of law, law science and legal information technology and to adjust legal theory and legal practice for the sake of a sense of justice in society. This study uses a normative juridical approach which refers to the applicable laws and regulations by examining secondary data on the principle of legal certainty, the principle of legal justice, the principle of legal usefulness as regulated in Act No. 4 of 2009 concerning Judicial Power. Based on the results of this study, there are differences in the meaning or terms between a release decision and an acquittal decision. In the judge's consideration in the case decision No.627/Pid/Sus/2018/PN.Smg, in his consideration the judge stated that the defendant's actions were proven but not a criminal act as in the indictment of the public prosecutor and in accordance with the Semarang District Court judge in imposing a crime having considered juridical, sociological and philosophical considerations, in deciding the decision to be released from all lawsuits (Ontslag Van Rechtvervolging) based on article 191 paragraph (2) of the Criminal Procedure Code, which reads "If the court is of the opinion that the act of which the defendant is accused is proven, but the act does not constitute a criminal act, then the defendant is acquitted of all lawsuits".
\end{abstract}

Keywords: Consideration, Judge, Release Decision

\section{Introduction}

Decisions are a product of judicial institutions in resolving disputes that occur in society, both in private and civil relations (general and religious), the relationship between the state and its citizens for violating criminal law regulations, decisions are not only a medium to declare someone guilty or as a means for someone. In order to be able to take back their rights which are controlled by others, however, decisions are substantially collaborative from the results of thought and deepening of the conscience which are packed with touches of theory and legal knowledge so that a decision will contain academic, logical and juridical values. ${ }^{1}$ It is not enough for a decision to be stated in writing, but also orally in an open session to the public. The principle of openness to the public is imperative. Trials and decisions pronounced in open sessions for the public are an integral part of the fair trial principle. ${ }^{2}$ However, with the reformation in 1998, the

\footnotetext{
1 Witanto, Darmoko Yuti \& Arya Putra Negara Kutawaringi. (2013). Diskresi Hakim sebuah Instrumen Menegakkan Keadilan Subtantif dan Perkara Pidana. Bandung: Alfabeta. p.32

2 Harahap, M. Yahya. (2005). Hukum Acara Perdata. Jakarta: Sinar Grafika. p.803
} 
affirmation of the presidential system of government was agreed upon in the agenda of the MPR session which discussed changes to the 1945 Constitution. ${ }^{3}$

Judgment of the decision consists of two parts, namely consideration of legal facts and legal considerations. Consideration of facts is obtained by examining the evidence empirically in the trial. The facts that were revealed at the trial were then tested using the correspondent theory of truth to obtain legal facts and clues. Legal considerations are a part of considerations that contain verification tests between legal facts and various theories and laws and regulations. Whether a crime is proven or not depends very much on legal considerations. ${ }^{4}$

A judicial body, the judge has the most important role because it is the judge who has the right to decide cases. Judges in carrying out their duties, especially in deciding a case, must always adhere to the principles of a free and impartial trial as stipulated in Article 1 of Act No. 4 of 2009 concerning Judicial Power which reads "Judicial power is the power of an independent state to administer judiciary in order to uphold law and justice based on Pancasila, for the sake of the implementation of the State of Law of the Republic of Indonesia ".5

Based on the description above, it can be seen that the judge in making decisions is based on various considerations. However, the judge's decision has often been controversial and widely opposed by various parties, such as the decision to leave all lawsuits (onslag van alle rechtsvervolging). Regarding the decision to release from all of these lawsuits, usually the public prosecutor will take legal action to a court with a higher level. The imposition of an independent decision from all lawsuits should truly reflect justice, which must be supported by existing evidence,

\section{Research Methods}

The approach method used in this research is a normative juridical approach. The juridical approach is an approach that refers to the prevailing laws and regulations. ${ }^{6}$ In this research, it is specified using qualitative research, namely research that does not make calculations. The purpose of this research is to gain understanding, develop theory and describe in a complex way about the object to be studied.7 Decomposition of the data analysis based on the information obtained from the respondents in order to achieve clarity on the issues discussed. From this analysis, it can be seen that the effectiveness of the legal system which is educative for the community in knowing the legal review of land grabbing is seen in the aspect of criminal law. The data source used in this study is secondary data, namely the data collection method is focused on existing, so that in this study it is not distorted and obscure in its discussion. a) Literature review. Data collection

\footnotetext{
${ }^{3}$ http://jurnal.unissula.ac.id/index.php/jurnalhukum/article/view/655

${ }^{4}$ Abdullah. (2008). Pertimbangan Hukum Putusan pengadilan. Surabaya: PT. Bina Ilmu Offset. Surabaya. p.51

${ }^{5}$ See Article 1 of Act No. 4 of 2009 concerning Judicial Power.

${ }^{6}$ Soemitro, Roni Hanitjo. (1982). Metode Penelitian Hukum dan Jurimetri. Jakarta: Ghalia Indonesia. p.20

7 Ediwarman. (2010). Monograf Metodologi Hukum. Sumatera Utara: Program Pascasarjana Univ.Muhammadiyah. p.24
} 
techniques are carried out by studying reference books, reports or previous research, magazines, journals and other media related to the object of research. Collecting data with literature study is collecting supporting data that links theory to reality. ${ }^{8}$ b) Documentation. The documentation method is a data collection method where data is obtained from books, the internet or other documents that support the research being carried out.

\section{Results and Discussion}

\subsection{Decision Release (Ontslag Van Rech Vervolging)}

The legal justice system in Indonesia does not adhere to the freie rechtslehre school (judges are free to do something/create laws) and the flow of legism (judges as mere implementers of laws), but adhere to the rechtsvinding school which is a combination of the freie rechtslehre and legism schools (bound judges in the Law, but has the freedom to create law/freedom that is bound/free of attachment). Therefore, even though there is a legal vacuum, the judge must play a role in making legal discoveries (rechtsvinding). In order to enforce the rule of law, it is necessary to have an institution called the judicative power (judicative power). Judicial power is exercised by state judicial bodies. The main duties of the judiciary are to examine, adjudicate, decide and settle cases filed by people seeking justice. The main actor who functionally exercises judicial power is the judge. There is a decision to release all lawsuits (Ontslag Van Rech Vervolging) in terms of proof, namely in the decision to release all lawsuits, what is being charged against the defendant is sufficiently proven legally, whether judged from the point of proof according to law or in terms of the minimum limit of proof. Which is regulated in article 183 KUHAP. However, an act that is proven "does not constitute a criminal act". Strictly speaking, the accused and proven acts are not regulated and do not fall within the scope of criminal law. But it may include the scope of civil law, insurance law, commercial law or customary law. ${ }^{9}$ The verdict of being free from all legal charges (Ontslag Van Rech Vervolging) in terms of prosecution, namely that the defendant was not acquitted of criminal threats, but "released from prosecution".10

According to the author, related to the meaning in the decision to release from all lawsuits is an impure verdict, if the verdict according to its skin or form contains the release of the defendant, while according to its content or substance it contains waiver of all lawsuits. Impure acquittal is the release of a disguised legal claim (Bedetk Ontslag van alle Recht Vervolging), if the indictment letter is formulated an element of a criminal offense with the same term as contained in law and the judge gives an incorrect interpretation of that term and also regarding such laws, even the interpretation is wrong so that the accusation is considered not proven.

\footnotetext{
8Sugiyono. (2013). Metode Penelitian Kuantitatif, Kualitatif dan R\&D. Bandung: Alfabeta. p.239

${ }^{9}$ Harangkap, M.Yahya. (2007). Pembahasan Permasalahan dan Penerapan KUHAP (edisi kedua). Jakarta: Sinar Grafika. p.352

${ }^{10}$ Ibid.
} 
According to the author, there are types of verdicts Ontslag Van Rech Vervolging because the charges made by the public prosecutor are proven to have committed an act but it is not a criminal act as in the indictment of the public prosecutor. In the type of decision which is free from all legal charges (Ontslag Van Rech Vervolging) in accordance with Article 191 paragraph (2) of the Criminal Procedure Code: If the court is of the opinion that the act accused of the defendant is proven, but the act is not a criminal act, then the defendant shall be acquitted of any lawsuits.

\subsection{Case Decision Process No.627/Pid/SUS/2018/PN.Smg}

Legal discovery can be interpreted as a process to find concrete laws against concrete legal symptoms/events which will later be formed by judges or related legal officers based on developments in society. In other words, there are times when judges in carrying out their professional duties and responsibilities must adjust the laws and regulations with real things because the existing regulations cannot cover all events that arise in society. So that decisions can be given that are truly fair and in accordance with the purpose of the law, namely to achieve legal certainty. The judge's duty in realizing justice cannot be separated from the decisions that are produced. Quality judges' decisions are obtained through the judge's thought process through the choice of judges that reflect judicial activism. ${ }^{11}$

The main function of a judge is to give a decision on a case submitted to him, where in a criminal case this is inseparable from the negative evidence system (negative wetterlijke), which in principle determines that a right or event or error is deemed proven, in addition to the existence of tools. Evidence according to law is also determined by the judge's conviction which is based on good moral integrity. The process or stages of making a decision by a judge, in a criminal case, according to Moeljatno, is carried out in several stages, namely:

- Stage of Analyzing Criminal Actions When the judge analyzes, whether the defendant committed a criminal act or not, the primary view is the aspect of society, namely the act as a form of a criminal rule

- Stage of Analyzing Criminal Liability If a defendant is found guilty of committing a criminal act of violating a certain article, the judge analyzes whether the defendant can be found responsible for the criminal act he committed.

- Determining Stage of Punishment The judge will pass the sentence if the elements have been fulfilled by observing the articles of the Law which the perpetrator violated. With the imposition of a sentence, the perpetrator is clearly a defendant. 12

In the process of a case verdict, it starts with the position of the case, the identity of the defendant, the indictment of the public prosecutor, the testimony of the public prosecutor's witness, the demands of the public prosecutor, the verdict. According to the author, the free decision handed down by the judge in case No. $627 / \mathrm{Pid} / \mathrm{SUS} / 2018 / \mathrm{PN}$ Smg is considered based on a criminal justice process in

\footnotetext{
${ }^{11}$ Amarini, Indriati. (2017). Keaktifan Hakim Dan Peradilan Administrasi. Purwokerto: Universitas Muhammadiyah Purwokerto Press. p.318

12 Rifai, Ahmad. (2010). Penemuan Hukum. Jakarta: Sinar Grafika. P.96
} 
accordance with positive law in Indonesia. The Panel of Judges in this case confirmed that the Defendant had been proven to have collected funds from the public but the Defendant's act was not a criminal act based on the indictment and charges handed down by the Public Prosecutor. The defendant was released from all lawsuits due to the following:

- One of the titles of the criminal law that was charged did not match a criminal act.

- There are special circumstances where the defendant cannot be convicted.

Judge's decision in case No. 627/Pid/SUS/2018/PN Smg is in line with the theory of Islamic justice. Fair in Islam means proportional to or according to the portion. According to the author, the judge has carried out his duties in accordance with the rule of law and has paid attention to the value of justice. A loose verdict can be viewed as fair and unfair, but if you look at the factors, it can occur that a release decision, in this case, is one of the names of the criminal law that is charged does not match the criminal act that has been committed. The author is of the view that the public prosecutor should not have given a single indictment, but that alternative charges could be given to anticipate or minimize the occurrence of a loose verdict.

\subsection{Judges' Considerations in the Decision to Release All Lawsuits in Case No.627/Pid/SUS/2018/PN.Smg}

The judge's decision is closely related to how the judge expresses his opinion or consideration based on facts and evidence at trial and the judge's conviction on a case. Therefore, judges have a central role in making court decisions. In a court decision, there must be considerations regarding matters that are burdensome and mitigate the verdict, these considerations are used as an excuse by the judge in making his decision whether in the form of other criminal decisions. ${ }^{13}$ Meanwhile, Article 197 letter f reads "Article of statutory regulations which are the basis of punishment or actions and statutory regulations which are the legal basis for the verdict, accompanied by conditions that incriminate and relieve the accused". ${ }^{14} \mathrm{As}$ law enforcers, judges have duties in the judicial field, namely receiving, examining, deciding and completing every case submitted to him. Justice seekers certainly desire that cases submitted to the court can be decided by a judge who is professional and has high moral integrity, so that decisions can be made in accordance with statutory regulations. ${ }^{15}$

According to Act No. 48 of 2009 concerning Judicial Power, the authority of judges in deciding a case has three aspects, namely:

- Receiving, reports that have been submitted to the judge, seeking information and evidence.

- Checking, looking carefully at the defendant's case file.

- Decide, the sentence of a case that is being examined and tried by the judge.

When exercising this authority, especially in adjudicating a judge's decision,

\footnotetext{
13 Article 197 letter d KUHAP.

${ }^{14}$ Article 197 letter f KUHAP.

15 Bambang, Sutiyoso. (2006). Metode Penemuan Hukum. Yogyakarta. p.5
} 
it is the crown and culmination of a case that is being examined and being tried by the judge. ${ }^{16}$ So the judge in making a decision must pay attention to all aspects in it, namely the indictment, the facts of the judge at trial, the condition of the community at trial. Apart from that, in accordance with Article 183 KUHAP a judge in imposing such a sentence is, unless with at least two valid evidence, the judge is convinced that a criminal act actually occurred and the defendant is guilty of committing it. The provisions of Article 183 KUHAP aim to guarantee legal certainty for a person (elucidation of Article 183 KUHAP). At least two pieces of evidence that are valid, have a purpose, namely at least two pieces of evidence that are valid according to the Criminal Procedure Code, evidence that is valid according to the Criminal Procedure Code as regulated in Article 184 paragraph (1) of the Criminal Procedure Code regarding the legal evidence in question is:

- Witness statement

- Expert Statement

- Letter

- Instructions

- Statement of the defendant or something that is generally known so it does not need to be proven. ${ }^{17}$

According to the author, the Semarang District Court judges have considered juridical, sociological and philosophical considerations in deciding the decision to release all lawsuits (Ontslag Van Rechtvervolging) based on article 191 paragraph (2) of the Criminal Procedure Code which reads "If the court is of the opinion that the act accused the defendant is proven, but the act does not constitute a criminal act, then the defendant shall be acquitted of all lawsuits". Judges' considerations are matters which form the basis or are considered by a judge in deciding a criminal case. Before deciding a case, a judge must pay attention to every important matter in a trial. The judge pays attention to the conditions for a person to be convicted, namely the subjective requirements and the objective requirements.

The role of judges in terms of decision making is not just done because something is decided is a legal act and is certain in nature. Therefore, judges who are given the authority to decide a case are not arbitrary in giving decisions.

Provisions regarding judges' considerations are regulated in Article 197 paragraph (1) d of the Criminal Code which reads:

"Considerations are drawn up briefly regarding the facts and circumstances along with the means of proof obtained from the examination at trial which are the basis for determining the guilt of the defendant."

Judges' considerations in the case decision No.627/Pid/SUS/2020 are in harmony with the theory of justice or Maslahat theory in an Islamic perspective which continues to be studied by philosophers of Islamic Law (Ushul Fiqh), especially when discussing the issue of maqashid tasyri 'or maqashid syari' Ah. The theory of justice based on an Islamic perspective is objective, comprehensive (world and hereafter) and universal. Judges consider juridically and sociologically,

\footnotetext{
${ }^{16}$ Rimdan. (2012). Kekuasaan Kehakiman. Jakarta: Pramedia Group. p.36

17 Rahardjo, Satjipto. (1998). Bunga Rampai Permasalahan dalam Sistem Peradilan Pidana. Jakarta: Pusat Pelayanan Keadilan dan Pengabdian Hukum. p.11
} 
which means that judges in considering decisions see social facts that occur in society, do not act arbitrarily. As is the case in Islamic justice which considers everything thoroughly and objectively.

\section{Conclusion}

The verdict is free from all charges law (Ontslag Van Rech Vervolging) In terms of evidence, namely in the decision to release all lawsuits, what is accused of the defendant is sufficiently proven legally, whether judged in terms of proof according to law or from the point of view of the minimum limit of proof stipulated in Article 183 KUHAP. However, an act that is proven "does not constitute a criminal act". And In the process of decision on case No.627/Pid/SUS/2020 starting from the position of the case, the identity of the accused, the indictment of the public prosecutor, the period when the defendant was in the state detention center, witness testimony from the public prosecutor. Judges' considerations in the decision are free from all lawsuits in the case No.627/Pid/SUS/2018/PN.Smg the court decision must contain considerations regarding things that are burdensome and mitigate the decision, these considerations are used as an excuse by the judge in making his decision both in the form of other criminal decisions.

\section{References}

Books:

[1] Abdullah. (2008). Pertimbangan Hukum Putusan pengadilan. Surabaya: PT. Bina Ilmu Offset. Surabaya

[2] Amarini, Indriati. (2017). Keaktifan Hakim Dan Peradilan Administrasi. Purwokerto: Universitas Muhammadiyah Purwokerto Press

[3] Bambang, Sutiyoso. (2006). Metode Penemuan Hukum. Yogyakarta

[4] Ediwarman. (2010). Monograf Metodologi Hukum. Sumatera Utara: Program Pascasarjana Univ.Muhammadiyah

[5] Harahap, M. Yahya. (2005). Hukum Acara Perdata. Jakarta: Sinar Grafika

[6] Harangkap, M.Yahya. (2007). Pembahasan Permasalahan dan Penerapan KUHAP (Second Edition). Jakarta: Sinar Grafika

[7] Rahardjo, Satjipto. (1998). Bunga Rampai Permasalahan dalam Sistem Peradilan Pidana. Jakarta: Pusat Pelayanan Keadilan dan Pengabdian Hukum

[8] Rifai, Ahmad. (2010). Penemuan Hukum. Jakarta: Sinar Grafika

[9] Rimdan. (2012). Kekuasaan Kehakiman. Jakarta: Pramedia Group

[10] Soemitro, Roni Hanitjo. (1982). Metode Penelitian Hukum dan Jurimetri. Jakarta: Ghalia Indonesia

[11] Sugiyono. (2013). Metode Penelitian Kuantitatif, Kualitatif dan R\&D. Bandung: Alfabeta

[12] Witanto, Darmoko Yuti \& Arya Putra Negara Kutawaringi. (2013). Diskresi Hakim sebuah Instrumen Menegakkan Keadilan Subtantif dan Perkara Pidana. Bandung: Alfabeta

Regulations:

[1] Article 1 of Act No. 4 of 2009 concerning Judicial Power 
[2] Article 197 letter d KUHAP

[3] Article 197 letter $f$ KUHAP

Internet:

http://jurnal.unissula.ac.id/index.php/jurnalhukum/article/view/655 